\title{
Anticipating deep autumn: a widening lens
}

\author{
L LaCivita Nixon, L A Roscoe
}

J Med Ethics: Medical Humanities 2002;28:82-87

Medicine has become one of the most powerful influences of the twentieth century, and currently dominates how we approach and think about another powerful phenomenon: the aging of the world's population. Our reliance on the medical model, with its focus on pathology, physiology, and biomedical interventions, makes it difficult for aging men and women and those in the health care field who care for them to seek alternative ways to attach meaning to the process of growing old. This article explores the role of the humanities as an alternative to the biomedical model which can enlarge our abilities to see the multidimensional aspects of aging. Age related writings and visual images by Kenyon, Neel, Olds, Valadon, and Hemingway are discussed to illustrate how fictive representations can and do serve as a moral impetus or stimulus for meaningful reflection about life stages that have not yet been experienced.

The writer, though ignorant of every scientific punctilio, will command the leap into the Other. That is how tales are made. ${ }^{\prime}$

See end of article for authors' affiliations

Professor L LaCivita Nixon, Division of Medical Ethics and Humanities College of Medicine-MDC 19, University of South Florida, 13901 Bruce B Downs

Blvd, Tampa, Florida 33612-4799,USA;

Inixon@hsc.usf.edu

Accepted 28 June 2002
$M$ edicine has become one of the most powerful influences of the twentieth century. It is not surprising that the medical model, with its focus on individual pathology, physiology, and biomedical interventions, currently dominates how we approach and think about aging and the ever growing number of older men and women in our society. The biomedicalisation of aging has fostered views of "inevitable decline, disease, and irreversible decay" and has convinced the public of the "primary and rightful place of medicine in the management of the 'problem' of aging". ${ }^{2}$ Where in the past religious interpretations about the place of aging in the human life course provided a sense of meaning and possibility, our reliance on the medical model for managing aging has made it more difficult for aging men and women to seek alternative ways to attach meaning to the process of growing old. ${ }^{3}$

Now that major demographic projections have moved from abstract statistics to concrete, real life family situations, newspaper accounts, economic forecasts, resource evaluations, and institutional limitations, the public is increasingly aware of the aging phenomenon and is beginning to look beyond medicine for interpretations, meanings, and options. In order to prolong life and prevent disabilities suffered by parents, many men and women at midlife and beyond are paying closer attention to diet, exercise, alternative medicine, and food supplements; increasing numbers of people are practising and promoting preventive care. In addition, this generally well educated, more affluent, and influential population cluster (including the so-called baby boomers) is dissatisfied with provisions for older people in society and has begun to speak articulately and persistently for change. By projecting themselves into their parents' lives, with an understanding that their own longevity continues to extend, this cohort is simultaneously euphoric and anxious. Partly because of undesirable impressions of institutionalised care combined with "Peter Pan" notions about prolonging youth, they both cling to and abhor their dependence on medicine and technology. Concerns about isolation, abandonment, and neglect have generated a new interest in choices, decisions, and experiences that have more to do with the values and purpose of human life. More people than ever before are attentive to subtle winds and tremors at early stages of what is foreseen as a very long autumn season.

In this article we explore the role of the humanities in enlarging our abilities to see the multidimensional aspects of aging and alternative ways of attaching meaning to the aging process. Age related writings and visual images by Kenyon, Neel, Olds, Valadon, and Hemingway are discussed to illustrate how "imaginative abilit[ies]" and fictive representations can and do serve as a moral impetus or stimulus for meaningful reflection about the objective other or stranger (who may soon be our mirror image). ${ }^{4}$ The selected pieces provide anticipatory insights from artists whose verbal or visual narrative looks ahead from midlife in the aging process to subsequent stages; in doing so, these anticipatory writings and paintings demonstrate Rorty's observations about the capacities of fiction to inspire or generate moral guidance about a life stage before it is actually experienced. The role and value of literature and art as tools or "vehicles of moral change and progress" is woven throughout the discussion as a necessary corollary for nourishing the human spirit in ways that the medical model cannot. ${ }^{4}$

\section{IMAGINATIVE ABILITIES}

For there will be the arts and some will call them soft data

whereas in fact they are the hard data by which our lives are lived. ${ }^{5}$

As a society, we remain fixed on inherited impressions and language or what Rorty calls the "final vocabulary" - the "set of words which 
[humans] use to justify their actions, their beliefs, and their lives" the familiar, comfortable language that has resulted in rigid patterns of thinking about and describing aging. ${ }^{6}$ Given the power and dominance of medicine in our culture to set values and priorities, the dominant narrative is one of decline and disease. Too often lines between being old and dying blur to form a singular image of hopelessness and finality in which older men and women are seen "as sickly, feebleminded, confined to nursing homes, a burden on their children, haggard and bitter". ${ }^{7}$ A portrait of aging provided by Barbara MacDonald-for example, derives from cultural fixations: "Old is ugly, old is powerless, old is the end, and therefore ... old is what no one could possibly want to be". ${ }^{8}$ On the other hand many older persons are what Moody calls "wellderly," able to take pleasure in travel, educational programmes, and leisure activities, and who, with their reduced obligations, may be enjoying newfound freedoms. ${ }^{\text {' }}$ Between these extremes realistic portrayals of aging point to complex, multidimensional patterns and textures, ranging from good health and active lifestyles to chronic and acute disease, marked by varying degrees of disability and ability to cope and compensate.

In order to get beyond the extreme images generated by the biomedical model and its culturally embedded notions and assumptions, Rorty suggests we exercise our "imaginative ability". ${ }^{4}$ In his writings about the possibility of a liberal utopia, he suggests that it is "to be achieved not by inquiry but by imagination, the imaginative ability to see strange people as fellow sufferers". ${ }^{4}$ He adds that the process of seeing "human beings as 'one of us' rather than 'them' is a matter of detailed description of what unfamiliar people are like and redescription of what we ourselves are like ..." ${ }^{\prime 4}$ When considering exactly where we need to go in our redescription efforts, Rorty explains that where the sermon and the treatise might have been useful tools in the past they have been replaced gradually and steadily by "the novel, the movie, and the TV program ... as the principal vehicles of moral change and progress". ${ }^{4}$

By creating characters who aren't us, but who could be, skilled writers and artists function to enlarge meanings or as Cynthia Ozick observes:

The writer, an imaginer by trade, will suggest a course of connection, of entering the tremulous spirit of the helpless, the fearful, the apart. The writer will demonstrate the contagion of passion and compassion that is known in medicine as empathy and in art as insight. ${ }^{10}$

Allowing for distanced entry into the world that may or may not yet be ours, fiction can thicken understandings about imagined experiences that we, too, are likely to share. Narrative dramas challenge habits or what Cole and Holstein describe as dichotomous thinking-“independence versus dependence, freedom versus coercion, body versus spirit, science versus religion" to forge connections between the objective "they" and the subjective "I". ${ }^{11}$ In terms of expanding levels of reflection, discussion, and constructive responses by individuals and society members, the wider, more inclusive, multilensed narrative provided by the humanities can serve as a valuable road map.

\section{FICTION AND ART: THE EXAMINED LIFE}

Poets, by nature are incapable of living the unexamined life. No detail is too small, no sound in the night too muffled, to register. From this gradual accumulation of minutiae, this keen awareness, poems emerge. $^{12}$
Entering into the lives of older persons by way of fiction and art provides a wide lens for looking at ranges of possibilities and perspectives about a population that is infinitely diverse. In a study of the role and value of humanities disciplines in 1980 the Commission on the Humanities reported that the disciplines make "distinctive marks on the mind: through history, the ability to disentangle and interpret complex human events; through literature and the arts, the ability to distinguish the deeply felt, the well wrought, and the continually engrossing from the shallow, imitative, and the monotonous; through philosophy, the sharpening of criteria for moral decision and warrantable belief". ${ }^{13}$ Several years ago Kirk Varnadoe, then director of the Museum of Modern Art, offered similar conclusions when he advised a graduating class at Stanford to "abandon the security of tradition ... . Art," he said, "doesn't offer predictable messages, but is most powerful when it orchestrates perplexity, fails to confirm what you already know, and instead sends you away temporarily disoriented but newly attuned to experiences in ways that are perhaps even more powerful because they are vague, rogue, and indeterminate."14 Varnadoe might have been speaking at a geriatrics conference about the nature of aging and the usefulness of writings like Rabbit at Rest by John Updike, As We Are Now by May Sarton, Old Friends by Tracy Kidder, and A Delicate Balance by Edward Albee. Narratives about aging, like those of lived lives, cannot be packaged into neat containers; those that are most valuable are messy, unfinished, and non-linear as in Faulkner's account of Dilsey in The Sound and the Fury, the portrayal of eight temporarily "lost" women in the film Strangers in Good Company, and the ongoing critiques surrounding the actions and expectations of the aged father and ruler in King Lear.

Fiction was described by Kafka as a liberating force, an axe to the frozen sea around us, a way to begin to "hear voices talking about everything in every possible way". ${ }^{15}$ The opportunity to hear the voices of others through fiction can be of enormous benefit to both aging persons, those looking ahead towards aging, as well as physicians and other health care providers who care for older persons. In recent decades humanities programmes have been added to the traditional and long standing medical school curriculum to enable students trained in scientific and clinical aspects of the human body to explore other aspects of the human condition that cannot be measured with ease and precision and to provide an opportunity to "develop a tolerance for ambiguity and ... [a] realiz[ation] that life is not always, not often, perhaps not ever categorized easily into the right answer and the wrong answer .. ." ${ }^{16}$ The so-called "soft data" ${ }^{5}$ or stories help to

make sense of ourselves and our world to ourselves and to others .... We tell tales-tales of truth, tall tales, tales of wisdom and woe-and listen to tales by others. Stories, with their beginnings, middles, and ends, redeem life from contingency and make it something other than a meaningless succession of events. ${ }^{17}$

Whether real or imagined, every telling of a story involves a series of choices about what will be revealed, what will be privileged, and what will be concealed; there are no artless narrations. Powerful stories, even-or especially-those about ordinary moments, do not go away. They remain stored in the receiver's mind until some event prompts recollection, then return uninvited and unexpectedly for further review, consideration, and personal editing. Consider the confessional thoughts of physician-writer, William Carlos Williams, who was seduced not only by the vibrancy of New York City's swirling literary and art currents but also by the humble "words being born" in the mouths of patients to reveal "a glimpse of something ... dazzling . . . a rare element . . . of mutual recognition". ${ }^{19}$ Amazed by what he saw and heard in the 


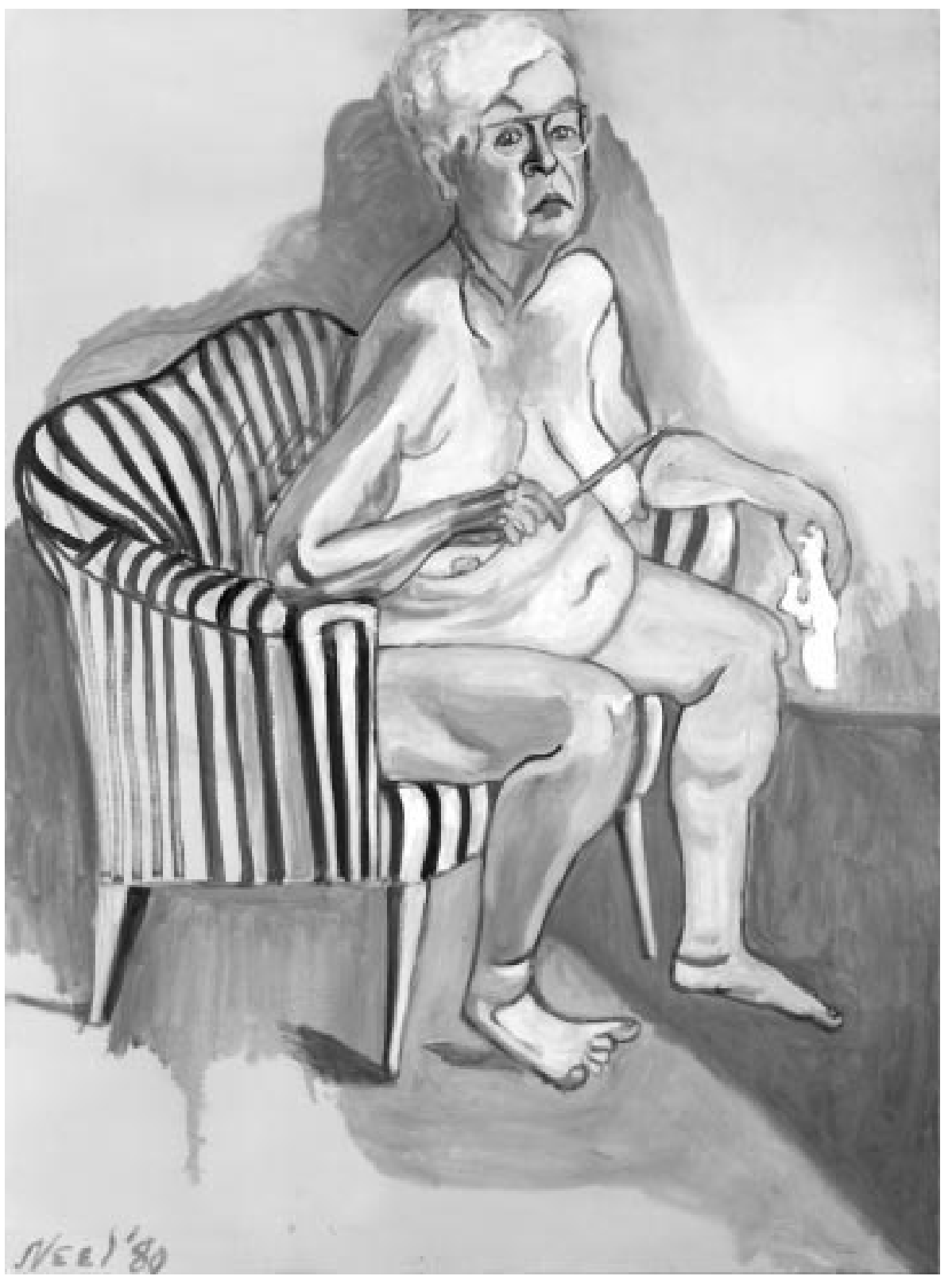

Figure 1 Alice Neel (American, 1900-1984). Self-Portrait, 1980. Oil on canvas, 54 x 40 in. The National Portrait Gallery, Smithsonion Institution, Washington, DC.

examining room or while making a house call, Williams marvelled at the power of story: its disturbing intrusiveness, stickiness, and ability to reappear voluntarily in the mind.

Visual images may be even less easily dismissed. Viewers of Alice Neel's Self-Portrait (figure 1) may discover that the image is deposited in the mind for unexpected recollection because the painting is unlike conventional portrayals of women in the male dominated art canon. Many viewers are caught off guard by Neel's reinterpretation of the gazed upon nude. Seated in a chair, and without apparent concern for sagging breasts and folds of skin on chin, abdomen, and thighs, the subject looks directly at the viewer through large glasses as an engaged participant in what has been called the "duality of being, the self as observer and observed". ${ }^{20}$

Viewers conditioned to more conventional depictions of erotic, youthful bodies may be disturbed by the bold depiction of a previously muted reality. More often than not, aging women have been disregarded: "impoverished, disrespected ... and dismissed . . a as inconsequential and uninteresting". ${ }^{21}$ By jolting "cultural fixations", 22 this humanistic portrayal by Neel serves to "transform historically idealized notions of the female body ... [and] "the tension between women's experiences and the socialized roles" that have denied their existence. ${ }^{23}$ "Here," says the subject, "is an older, non-nubile, non-reclining female you have avoided, made invisible. Here I am."'23

In this century, Neel's contributions and those of other women have radically revised earlier impressions and conclusions and made visible what had been invisible: Eudora Welty's photographic collection of black women living lives of hardship and struggle; Kathe Kollwitz's woodcuts of women-at times fiercely protective and then, when very old and stooped, submissive to an anthropomorphic death; and iconoclastic sounds from Doris Grumbach, Maxine Kumin, May Sarton, Marge Piercy, and Jane Kenyon, as they and their narrators speak subjectively about previously unexpressed women's experiences and concerns. It is not surprising that these writers have directed attention to aging's trials, tribulations, and celebrations. ${ }^{24}$

The Pear by Jane Kenyon illustrates how poetry about the aging process can bring the narrator and engaged readers 
together. ${ }^{25}$ Unlike any entry in a medical text about aging, the poem's transfixing moment turns the personal story inside out to shift the meditative focus from narrator to reader. By eliciting reader contemplation, a double focus is created; the fictive inventory enlarges and deepens unique perspectives about physicality in a shared life course.

\section{The Pear}

There is a moment in middle age when you grow bored, angered by your middling mind, afraid.

That day the sun

burns hot and bright,

making you more desolate.

It happens subtly, as when a pear

spoils from the inside out,

and you may not be aware

until things have gone too far. ${ }^{25}$

When a narrator, such as this one, reflects on her body as it has become, she is taking stock of where she is in life. At some point most of us do the same thing and become quietly stunned to see how far "things have gone". Like her, we may be suddenly "afraid". Without time lapse photography, aging is a subtle process, as with a pear that has moved imperceptibly past ripeness. Nevertheless, there are moments of confrontation, discovery, blunt awareness that catch us by surprise. Caught in the sticky filaments of fictional content and style, an empathetic connection is made between narrator and reader:

Reader and writer merge, through the medium of the text, to become a collective being that both writes as it reads and reads as it writes, and creates, jointly, that unique work, "their" novel. ${ }^{15}$

Kenyon's poem has an amplifying effect on readers who are invited to join the narrator in mutual contemplation, objectively, at first, then, subjectively. The poet serves as moral conduit whose fictive context moves readers to think about a shared aging process. Writers put readers into the picture: with the safety of distance, readers begin to see that they, too, have much to share with the narrative situation. Our bodies, no matter the chronological age, like that of the narrator, are in a continuous process of change. Responses vary, of course. Some recognise and accept the aging "moment" easily, as inevitable; others will resist such thoughts; and many will work hard to postpone preventable change by way of exercise, nutrition, surgery, etc. Kenyon's poem brings about a convergence with the reader's own beliefs, assumptions, and vulnerabilities; it encourages thought and discourse about shared concerns and doubts. As Jack Coulehan and Angela Belli recently suggested in the preface to Bone and Blood, readers

can best probe the mysteries of human existence through the uses of the intellect in concert with the imagination. The power of communicating and the sensibility to absorb and transmit intense conceptions regarding humanity and nature reside in the poet, who surpasses the machine by a capability to, in Shelley's words, "measure the circumference and sound the depths of human nature with a comprehensive and all-penetrating spirit". ${ }^{26}$

Reflection that occurs along separate and collectives journeys through life makes it more difficult to separate them (those who are old) from us. Stories function as connectors or bridges between them to us making us more aware of and responsible toward aging's personal and social obligations.
In a vanitas poem-that is a poem which projects or examines one's mortality-entitled 35/10 Sharon Olds illustrates how poetry provides another example of double focus for shared personal inventory and moral reflection during a mother's ruminative moment. ${ }^{27}$ While brushing her daughter's "dark silken hair," the narrator/mother (age 35), suddenly aware of her own gray hair in the mirror, is prompted into reflection about the child's (age 10) becoming and her own going. Why is it she asks that

just as we begin to go

they begin to arrive, the fold in my neck

clarifying as the fine bones of her

hips sharpen $?^{27}$

This, the mother muses, "is the story of replacement". As her own skin begins to dry and her body "snaps its [reproductive] clasp," the daughter's "purse" fills with "eggs, round and firm as hard boiled yolks". The mirror brings the "oldest story" into focus, a moment when loss and renewal are captured simultaneously. By presenting details about a specific human experience of becoming and declining, Olds's narrator brings the reader into a subjective realm in which larger meanings can be extracted from the fictional realm that are similar to those experienced by readers. The engaged or willing reader makes connections between the fictive context and the self to encourage or instill personal examination and an acceptance of life's rhythmic patterns.

Another related narrative dealing with the same theme of reflexivity about the aging process-and possibly the inspiration for the poem by Olds - is Suzanne Valadon's painting, The Abandoned Doll (figure 2). Having set the stage with numerous

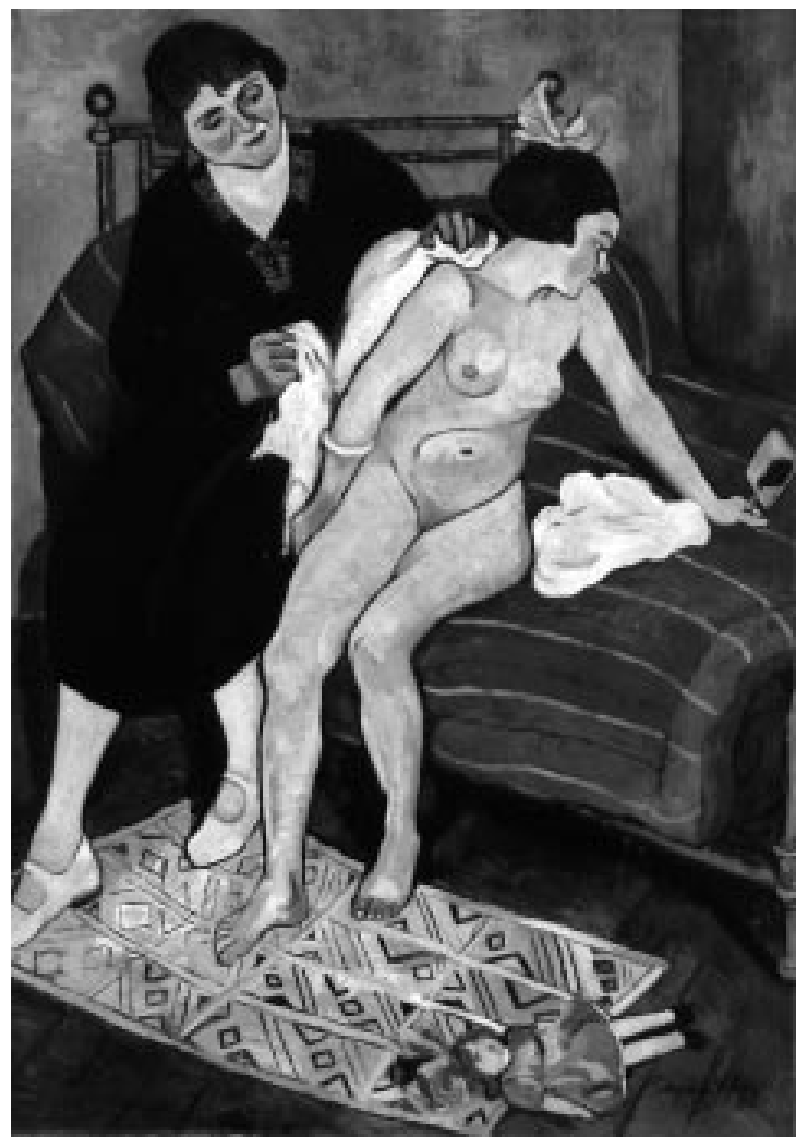

Figure 2 Suzanne Valadon (French, 1888-1981). The Abandoned Doll, 1921. Oil on canvas, $51 \times 32$ in. The National Museum of Women in the Arts. Gift of Wallace and Wilhelmina Holladay. 
props for viewers to consider, Valadon invites them to construct a story or narrative. That the pubescent girl is seated naked on the bed produces a radical, even startling, departure from domestic scenes created-for example, by Mary Cassatt during the same late 19th, early 20th century period of time and serves as a signal that Valadon has violated subject matter rules imposed by the male ordered world. The painting appears heavily loaded with subjective meanings about being female and moving from adolescence to midlife. The childhood doll has been cast aside and soon the bow will disappear from the young woman's hair. A mirror for self examination, symbolising adolescent fascination with the changing body, becomes a prompt, as well, for the mature woman, presumably the mother, to consider changes in her aging self. One has the future before her, while the other is moving toward decline and aging. Valadon's representation of this reality is beautifully portrayed in A Clean, Well-Lighted Place by Ernest Hemingway, a short story set in a café in which two opposing viewpoints are expressed for readers to follow. ${ }^{28}$ The story concerns two waiters, one young, the other older, and an old, only "slightly drunk" man, who comes regularly for brandy to their well lighted and pleasant bodega. Unnamed, the man is very old, deaf, and now that his wife has died, alone. Long after other patrons have left, he sits nursing his drink and becomes the discussion topic for the waiters who await his departure before going home themselves. The younger waiter is openly impatient; he is unmoved and annoyed by the old man, even when his more reflective and sympathetic partner mentions that the patron had tried to commit suicide last week. "'He'll stay all night', he says. 'I'm sleepy now. I never get into bed before three o' clock. He should have killed himself last week'."'

Later, when grudgingly responding to a request for more brandy, he pours only a small amount while saying to the unhearing man: "You should have killed yourself last week". ${ }^{29}$ When the shortchanged old man motions with his finger for a "little more" brandy, the young waiter rudely overfills the glass causing the brandy to slop over the rim, down the stem, and onto the saucer. Ignoring or oblivious to the waiter's pettiness, the old man responds to the action with a simple "thank you". ${ }^{29}$

The young waiter dismisses the old man as an object, a "nasty thing". ${ }^{30}$ Distanced and detached, he declares ironically: "I wouldn't want to be that old". ${ }^{30}$ Unlike his careless colleague, the older waiter is wiser and more patient with the old man's situation. By temperament, experience, and insight, he seems to understand that the clean, well lighted café is a stand against darkness, chaos, nada-a huge, overbearing, inevitable nothingness for one very old man whose life is suspended between the lighted café and the darkness of death. The old man and older waiter sense what the younger waiter misses: loneliness and isolation, but with knowledge that "parts of ... [the] world are salvageable", places where dignity can be retained..$^{31}$ The clean, well lighted café forms "a bulwark against the nothingness because it is concrete and immediate, not abstract or eternal". ${ }^{31}$

The tenderness exhibited by the senior waiter towards the old man shows a nobility of spirit that most readers will applaud. Those with parents or loved ones in nursing homes worry about, and may have first-hand knowledge of, diminishment, disrespect, and loss of dignity. That the old man struggles nightly to reach the lights of the café is important; that one waiter behaves rudely and dismissively is an appalling reminder of what too many aging persons face.

\section{PERSONAL, SOCIAL, AND MORAL OBLIGATIONS}

Deep autumn

My neighbor, how

Does he live, I wonder? ${ }^{32}$
When serious and sustained consideration is given to older people-what aging is, what it means for them, for us, for the human adventure-we begin to understand that no single thread can be followed and no single story will suffice. The haiku by Basho presents a succinct outline for those engaged in these mediations but more importantly the poem enunciates a moral message and obligation. Line one establishes a setting; line two, the character, and parts of lines two and three, the plot line: how does he live? Then, as an almost casual rumination or afterthought: "I wonder?" Not unlike once upon a time, the childlike question is compellingly inclusive and moralistic in function. By invoking wonder-a word meaning to think, imagine, or speculate about, to be filled with admiration, amazement, or awe, to be excited by the strange and surprising - the poet is underscoring moral responsibility associated with thinking about or imagining the situation of aging "neighbours" and himself during the deep autumns of their lives. A moral society is based on community: "one's sense of obligation to other human beings" ${ }^{33}$ If the narrator in Basho's haiku wonders out loud about his aging neighbour's circumstances during deep autumn, shouldn't the reader do so as well? To do otherwise is morally unacceptable and socially irresponsible.

In another reading of the haiku, Basho's reflections may be about the proximity of his own "deep autumn", about his own impending old age. This interpretation also contains a moral dimension: the responsibility to take ownership and personal control of the meaning of our own aging experience. It may be simpler to rely on received wisdom, conventional archetypes, and medical decrees, but creating for oneself an old age that is rich in possibility and insight requires a personal investment.

The haiku's call for social and personal responsibility presents an implicit obligation to listen to stories-our own as well as those of others-so that we can hear different voices, complexities, and nuances relating to the subjective worlds and interpretive experiences of aging that transcend our inherited assumptions. By submitting to the pull of the text we are engaged in roles required of us as readers; we give substance to the imagined world and the psychological life of its inhabitants. The humanities-literature, art, theatre, film, etc-extend our perceptions, intensify our reflections, and enlarge our feelings about our own experiences and those of others. As illustrated by the images and writings selected for this discussion, we are first stirred by the situational context and then, centripetally by direct and indirect relation to our families, friends, neighbours, and selves.

In the Defence of Poetry Percy Bysshe Shelley attributed to poetry a moral dimension that enables poets to form connections with others. To be great and good, said Shelley,

a man must imagine intensely and comprehensively; he must put himself in the place of another and of many others; the pains and pleasures of his species must become his own. The great instrument of moral good is the imagination and poetry administers to the effect by acting upon the cause. ${ }^{34}$

Like the narrator in the Basho haiku, Shelley's vision of the good and moral requires not just a consideration of others but an imaginative exploration of possibilities or what Rorty calls the "contigency of community". ${ }^{35}$ The narrowly focused lens of medicine-for example, is enlarged by fiction to suggest other ways of seeing, describing, interpreting, and deciding about aging. Like Shelley, John Dewey proclaimed imagination the "chief instrument of good ... and more moral than the moralities". "For the latter either are, or tend to become," he said, "consecrations of the status quo .... The moral prophets of humanity have always been the poets ...." ${ }^{\prime 36}$ With uncanny ability writers, poets, and artists evoke curiosity and concern about recognisable motivations and consequences of human life so that those 
who have no pain can imagine those who suffer. Those at the center can imagine what it is to be outside. The strong can imagine the weak. Illuminated lives can imagine the dark. Poets in their twilight can imagine the borders of stellar fire. We strangers can imagine the familiar hearts of strangers. ${ }^{10}$

\section{ACKNOWLEDGEMENT}

The Pear, copyright 1996 by the Estate of Jane Kenyon. Reprinted from Otherwise: New and Selected Poems with the permission of Graywolf Press, Saint Paul, Minnesota.

\section{Authors' affiliations}

L LaCivita Nixon, L A Roscoe, College of Medicine, University of South Florida, Tampa, Florida, USA

\section{REFERENCES}

1 Ozick C. Metaphor and memory. New York: Alfred A Knopf, 1985: 283.

2 Estes CL, Binney E. The biomedicalization of aging: dangers and dilemmas. The Gerontologist 1989;29:587-96.

3 Cole T, Holstein M. Reflections on age, meaning, and chronic illness. Journal of Aging and Identity 1996;1:7-22.

4 Rorty R. Contingency, irony, and solidarity . Cambridge: Cambridge University Press, 1989: xvi.

5 Stone J. Gaudeamus igitur: a valediction. Renaming the streets. Baton Rouge, Louisiana: Louisiana State University, 1985: 43.

6 See reference 4: 73

7 Nemeth M. Amazing greys. Maclean's 1994 Jan 10: 26-9.

8 Macdonald B, Rich C. Look me in the eye: old women, aging, and ageism. San Francisco: Spinsters Ink, 1980: 91

9 Moody H. Cited by Rosenthal J. The age boom. The New York Times Magazine 1997 Mar 30: 42

10 See reference 1: 266

11 See reference 3: 20

12 Rehak M. Poetic justice. New York Times Review of Books 1999 Apr 4: 15.

13 Wear D, Kohn M, Stocker S, eds. Literature and medicine: a claim for a discipline. McLean, VA: Society for Health and Human Values, 1987: 12.
14 Varnadoe K. Commencement. The New York Times 1992 Jun 15: Al1.

15 Rushdie S. Is nothing sacred? The Herbert Read Memorial Lecture. Granta 1990;10:2-16.

16 Jones AH, Banks JT, Greene $M$, et al. Teaching literature in medical schools. In: Wear D, Kohn M, Stocker S, eds. Literature and medicine: a claim for discipline. McLean, Virginia: Society for Health and Human Values, 1987: 63-74.

17 Carson R. The moral of the story. In: Nelson HL, ed. Stories and their limits. New York: Routledge, 1997: 233-7.

18 Williams WC. The autobiography of William Carlos Williams. New York: New Directions, 1951: 361 .

19 See reference 18: 360 .

20 Wolff J. Feminine sentences: essays on women and culture. Berkeley: University of California, 1990: 295.

21 Healy S. Growing to be an old woman: aging and ageism. In: Alexander J, Berrow D, Domitrovich L, et al, eds. Women and aging: an anthology by women. Corvallis, Oregon: Calyx Books, 1986: 58-62.

22 See reference 4: vi.

23 Bauer D. Alice Neel's female nudes. Women's Art Journal 1994; 15:21-6.

24 Until recently, few male writers were subjective in scope; foundations of the patriarchal worldview were based on objective perspectives with little room for or interest in self reflexivity. Increasingly, male writers and artists such as Stephen Dunn, Raphael Campo, William Matthews, Donald Hall, Tim O'Brien, Lucien Freud, and Robert Mapplethorpe have begun to move beyond inherited borders of propriety to speak subjectively about personal matters.

25 Kenyon J. The pear. Otherwise: new and selected poems. St Paul, Minnesota: Graywolf Press, 1990: 10.

26 Coulehan J, Belli A, eds. Blood and bone. lowa City: University of lowa Press, 1998: xvi.

27 Olds S. The dead and the living. New York: Alfred A Knopf, 1983: 75.

28 Hemingway E. A clean, well-lighted place. The snows of Kilimanjaro and other stories. New York: Charles Scribner's Sons, 1961: 29-33.

29 See reference 28: 30 .

30 See reference 28: 31 .

31 Benson J. Hemingway: The writer's art as self-defense. Minneapolis: University of Minnesota Press, 1969: 28.

32 Basho. In: Mayes F. Bella Tuscany. New York: Broadway Books, 1999 176.

33 See reference 4: 59

34 Shelley PB. A defence of poetry. In: Ingpen R, Peck WE, eds. The complete works of Percy Bysshe Shelley. London: The Julian Editions 1965, 8: 118.

35 See reference 4: 49-69.

36 Dewey J. Art as experience. New York: Capricorn Books, 1958: 348. 